\title{
Business Process Modelling Perspectives Analysis
}

\author{
Renate Strazdina and Marite Kirikova \\ Riga Technical University \\ Kalku iela 1, Riga, LV-1010 \\ \{Renate.Strazdina, Marite.Kirikova\}@cs.rtu.Iv
}

\begin{abstract}
Business process modelling has long been important both for IS development and organization performance optimization. In addition, as demonstrated by practical experience derived from cooperation with organizations it is necessary to design an approach allowing the translation of business processes modelled in a particular perspective to other perspectives - which is not always possible under the existing modelling approaches. This paper brings together business process modelling perspectives that have found their reflection in various existing enterprise architectures. The existing business process modelling perspectives are grouped based on the underlying semantic meaning and analysed from the following viewpoints - the modelling scale and possible values and interrelation between different business process modelling perspectives.
\end{abstract}

Keywords: business process modelling, enterprise architecture, multidimensional modelling.

\section{Introduction}

Business process modelling has long been important both for IS development and organization performance optimization. In many cases business process modelling has been developing as part of the enterprise architecture realm. In addition, an analysis of the existing enterprise architectures shows that business process modelling is presented from different perspectives in different enterprise architectures, thus evidencing the correlation between business process modelling perspectives and the final goal and future use of the model. However, as demonstrated by practical experience derived from cooperation with organizations, it is necessary to design an approach allowing the translation of business processes modelled in a particular perspective to other perspectives - provided such a transformation is semantically possible. This is also confirmed by assorted research [1] Besides this, in an organizational context business processes are performed and constructed by people "owning" different business perspectives, therefore it is reasonable to consider the possibility of constructing a multidimensional business process model in a multidimensional business process modelling space where one modelling dimension can consist of a set of different business perspectives.

This article brings together business process modelling perspectives (business perspectives) that have found their reflection in various existing enterprise architectures, 
thus enabling one to grasp the scope of requirements organizations pose towards business process models. The existing business process modelling perspectives are grouped based on their underlying semantic meaning and analyzed from the following viewpoints: modelling scale and possible values and interrelation between different business process modelling perspectives.

The paper is structured as follows: The overview of business process modelling perspectives selected from related works is presented in Section 2; the analysis of the existing business process perspectives is presented in Section 3; and Section 4 consists of conclusions and points to directions of future work.

\section{Enterprise Architectures and Business Process Modelling Perspectives}

"'Architecture', in a broad sense, is the synergy of art and science in designing complex structures, such that functionality and complexity are controlled... architecture, hence, is concerned with understanding and defining the relationship between the users of the system and the system being designed itself" [2]. With respect to enterprise architectures, the notion of a business process model frequently appears in definitions of the architectures [3] or enterprise architecture frameworks [4, 5].

By analyzing different enterprise architectures' products it was found that there are many different business perspectives embedded in these architectures and the sets of perspectives used in different architectures are different. The existing business process modelling perspectives are presented in Table 1. The first column reflects all business process modelling perspectives obtained from the analysis; the following columns show the enterprise architectures' products analysed (denoted by Roman numerals which are explained below the table). The plus signs in the cells of the table present the enterprise architecture products which include the particular perspective.

Multiple interrelated terms are used in this article that are known in the business process modelling discipline - perspective, dimension, modelling scale and values. An analysis of assorted research results $[1,4,5]$ showed that different terms are used in business process modelling to describe the same artefacts; it was also noted that the definitions of these terms are not always unambiguous.

The following term definitions are used for the purposes of this research: Business process modelling perspective - a business process parameter that can be included in a model but cannot be placed in a separate swimlane, where a swimlane is a visual mechanism of organizing different activities into categories of the same functionality. Business process modelling dimension is notion derived from mathematics where the dimension of a space is roughly defined as the minimum number of coordinates needed to specify every point within it [6]. In case of business process modelling it can be applied as well - dimension is a set of parameters or one particular parameter associated with the particular business process and these parameters allow reflecting the real world in models. A necessary condition is the possibility of placing a dimension in a separate swimlane. Two categories of dimensions are specified in this research: Simple dimensions consisting of one parameter, e.g. time, and structural dimensions consisting of a multitude of parameters. Scale is a concept related to business process modelling dimension; this concept determines what swimlanes are 
required. As an example, a time dimension scale can be a month or a minute. The scale of a structural dimension is expressed as the granularity of the elements reflected by the dimension or the number of decomposition / abstraction levels. It is necessary to note that structural dimensions can be decomposed into subdimensions with different scales. Value is also a business process modelling dimension-related concept that determines the denominations on the swimlanes created; these could be the names of the days of the week or months for the time dimension.

Table 1. Business process perspectives revealed from enterprise architecture frameworks

\begin{tabular}{|c|c|c|c|c|c|c|c|c|c|}
\hline Perspectives & I & II & III & IV & V & VI & VII & VIII & IX \\
\hline Mission, vision, strategy & + & & + & + & + & + & & & + \\
\hline Business goals & + & & & & + & + & & + & + \\
\hline $\begin{array}{l}\text { Organizational structure (process } \\
\text { performers, owners, planners, } \\
\text { designers, etc) and roles }\end{array}$ & + & + & + & + & + & + & + & + & \\
\hline Knowledge, information, data & + & + & + & + & + & + & + & + & + \\
\hline Geographical space & + & & + & & + & & & & \\
\hline Time & + & + & & & & + & + & & \\
\hline Event & + & + & & + & + & & + & + & \\
\hline State & & + & & + & & + & & & \\
\hline Function & + & + & + & + & & & + & + & + \\
\hline Services & & & + & & + & + & & & + \\
\hline Rules & & + & & & & $+^{*}$ & + & + & \\
\hline System controls & + & & & & + & & + & & + \\
\hline $\begin{array}{l}\text { System performance parameters/ } \\
\text { resource capability }\end{array}$ & & & & + & + & & & + & + \\
\hline System requirements & & + & + & & + & & + & & + \\
\hline Standards (compliance) & & + & & + & + & & & & + \\
\hline $\begin{array}{l}\text { Interface with business process } \\
\text { support system (software and } \\
\text { hardware) }\end{array}$ & + & + & + & + & + & + & + & + & + \\
\hline $\begin{array}{l}\text { Business process support system } \\
\text { (software and hardware) }\end{array}$ & + & + & + & + & + & + & + & + & + \\
\hline
\end{tabular}

* cultural

I - Zachman's Matrix of Architectural Views [7], II - The Department of Defense Architecture framework (DODAF) [4], III - Federal Enterprise Architecture Framework (FEAF) [8, 9], IV - Treasury Enterprise Architecture Framework (TEAF) [9], V - Microsoft Enterprise Architecture [10], VI - Extended Current Enterprise Architecture [11], VII - The Extreme Architecture Framework [12], VIII - CIMOSA Application server project architecture [13], IX - TOGAF [4]

An analysis of the existing business process modelling perspectives shows that some of these are semantically similar and thus can be grouped together. This gives rise to the perspectives classification presented in Table 2. By using expert evaluation six different groups were defined based on semantic similarities: 1) Strategic level perspectives; 2) Information system requirements level perspectives; 3) Structure level perspectives; 4) Event level perspectives; 5) Function level perspectives; and 6) Data level perspectives. 
Based on the defined groups it is possible to find the source / sources of each group - i.e., where the information necessary for developing the model can be found in the organization or its external environment. In addition, further research could help answer whether perspectives belonging to one group and the corresponding dimensions have any other common features - e.g., how detailed the model can be / is worth creating, what links exist with other perspectives or dimensions and who are the users of the model created in a particular dimension.

Table 2. Groups of business process modelling perspectives

\begin{tabular}{lc}
\hline \multicolumn{1}{c}{ Perspectives } & Group \\
\hline Mission, vision, strategy & Group 1 \\
Business goals & Group 1 \\
$\begin{array}{l}\text { Organizational structure (process performers, owners, planners, designers, etc) } \\
\text { and roles }\end{array}$ & Group 3 \\
Knowledge, information, data & Group 6 \\
Geographical space & Group 3 \\
Time & Group 4 \\
Event & Group 4 \\
State & Group 5 \\
Function & Group 5 \\
Services & Group 5 \\
Rules & Group 2 \\
System controls & Group 2 \\
System performance parameters/ resource capability & Group 2 \\
Systems requirements & Group 2 \\
Standards (compliance) & Group 2 \\
Interface with business process support system (software and hardware) & Group 2 \\
Business process support system (software and hardware) & Group 2 \\
\hline
\end{tabular}

The individual business process modelling perspectives from the Group 2 were analyzed to determine whether each of them can be treated as a business process modelling dimension - i.e. whether it can be depicted as a separate swimlane in a business process model (see Section 3). The swimlane in a business process model was taken as the main criteria because of the fact that swimlane is a visual mechanism of organizing different activities into categories of the same functionality.

\section{Analysis of Business Process Modelling Perspectives}

As it was stated in the previous section the following definition of dimension is adopted for the purposes of this paper - dimension is a set of related parameters associated with the process where the parameters refer to particular business process modelling perspectives, e.g time dimension (sequence, execution time, start time, end time), standards dimension (rules, system controls, standards compliance) - defined for enterprise architectures that where analysed in the previous section.

To determine the split by dimension of the parameters mentioned in the previous section an analysis based on the perspectives' business essence was carried out. The 
Table 3. Business process modelling perspectives and associated dimensions

\begin{tabular}{|c|c|c|c|}
\hline Perspectives & Dimension & Scale & Values \\
\hline Rules & $\begin{array}{l}\text { Standards dime- } \\
\text { nsion }\end{array}$ & $\begin{array}{l}\text { Standards main } \\
\text { requirements } \\
\text { (vertically) }\end{array}$ & $\begin{array}{l}\text { Depends on the particular } \\
\text { standard }\end{array}$ \\
\hline System controls & & $\begin{array}{l}\text { Controls associ- } \\
\text { ated with process } \\
\text { (described in the } \\
\text { process) }\end{array}$ & $\begin{array}{l}\text { Performance parameters } \\
\text { (time, sequence, speed, } \\
\text { duration, volume), re- } \\
\text { source capability, in- } \\
\text { put/output controls }\end{array}$ \\
\hline Standards compliance & & $\begin{array}{l}\text { Compliance matur- } \\
\text { ity level (like } \\
\text { maturity level in } \\
\text { Capability maturity } \\
\text { model) } \\
\text { (horizontally) }\end{array}$ & $\begin{array}{l}0-5 \text { (if we use for exam- } \\
\text { ple Capability maturity } \\
\text { model approach) }\end{array}$ \\
\hline $\begin{array}{l}\text { System performance } \\
\text { parameters/resource } \\
\text { capability } \\
\text { (if we are in the process } \\
\text { of system requirements } \\
\text { definition then it could } \\
\text { be associated with the } \\
\text { systems requirements } \\
\text { dimension, otherwise it } \\
\text { could be the standards } \\
\text { dimension (e.g. if we are } \\
\text { developing workflow } \\
\text { model (executable))) }\end{array}$ & $\begin{array}{l}\text { System require- } \\
\text { ments dimension } \\
\text { or Standards } \\
\text { dimension }\end{array}$ & $\begin{array}{l}\text { Types of system } \\
\text { requirements } \\
\text { according to stan- } \\
\text { dards (e.g. IEEE) }\end{array}$ & \\
\hline $\begin{array}{l}\text { Systems requirements } \\
\text { (we assume that one } \\
\text { particular requirement of } \\
\text { the system is a parameter } \\
\text { of a process, so system } \\
\text { requirements combined } \\
\text { are a set of parameters or } \\
\text { dimension) }\end{array}$ & $\begin{array}{l}\text { Systems } \\
\text { requirements } \\
\text { dimension }\end{array}$ & $\begin{array}{l}\text { Types of system } \\
\text { requirements } \\
\text { according to stan- } \\
\text { dards (e.g. IEEE) }\end{array}$ & $\begin{array}{l}\text { Functional; non- } \\
\text { functional requirements, } \\
\text { performance require- } \\
\text { ments, security require- } \\
\text { ments etc. }\end{array}$ \\
\hline $\begin{array}{l}\text { Interface with business } \\
\text { process support system } \\
\text { (software and hardware) } \\
\text { (if we are in the process } \\
\text { of system requirements } \\
\text { definition then it could } \\
\text { be associated with the } \\
\text { systems requirements } \\
\text { dimension, otherwise it } \\
\text { could be the integration } \\
\text { dimension) }\end{array}$ & $\begin{array}{l}\text { Systems re- } \\
\text { quirements } \\
\text { dimension or } \\
\text { integration } \\
\text { dimension }\end{array}$ & $\begin{array}{l}\text { Reason of integra- } \\
\text { tion (integration } \\
\text { dimension only) }\end{array}$ & Input/Output/Support \\
\hline $\begin{array}{l}\text { Business process support } \\
\text { system (software and } \\
\text { hardware) }\end{array}$ & $\begin{array}{l}\text { Integration } \\
\text { dimension }\end{array}$ & $\begin{array}{l}\text { Reason of } \\
\text { integration }\end{array}$ & Input/Output/Support \\
\hline
\end{tabular}


analysis was based on the following principles: The source of the perspectives that belong to the perspectives group (see Table 2) was defined based on empirical evidence and an analysis of relevant literature. If the source coincided for multiple perspectives and the perspectives were semantically close, and if they could also be presented in a single swimlane, a dimension was defined. For example, the source of rules, system controls, and standards compliance is standards (which, of course, can be very different). As such, this forms a structural dimension that can have up to three parameters (see Table 3). The scale was derived from an analysis of realistic business process models where the respective perspective was modelled. The values followed from the defined scale.

As an example of the results of the analysis done regarding the perspectives of the Group 2 are presented in the Table 3.

As the analysis of business process modelling perspectives shows not all of them are separate business process modelling dimensions, however one perspective can be associated with different dimensions - this depends on the objective of the modelling process. Every dimension has a modelling scale associated with it and a possible range of values.

The results of this analysis show that when analyzing business processes it is crucial to include all the information necessary for building a model that would allow transforming modelling results from one modelling dimension to other(s) as well as demonstrate the connection and interdependence of the modelling dimensions.

\section{Conclusions}

This paper reflects an early stage of a research on business process modelling in different perspectives. The paper contains analysis of business process modelling perspectives that are a part of the existing enterprise architectures' products. These perspectives have been analyzed to determine if each of them can be viewed as a separate business process modelling dimension. Where this was not possible perspectives were combined to make up a dimension.

Further research will test the dimensions outlined in this paper by modelling reallife situations. Further research will also be made into the interdependence of the dimensions and perspectives in order to assess the feasibility of transforming business process models modelled in one dimension to other dimensions.

\section{References}

1. Dreiling, A., et al.: From conceptual process models to running systems: A holistic approach for the configuration of enterprise system processes, Decision Support Systems (2007)

2. Vissers, C.A.: A preface for Lankhorst M. et al., Enterprise Architecture at work: Modelling, Communication, and Analysis. Springer, Heidelberg (2005)

3. Lankhorst, M., et al.: Enterprise Architecture at work: Modelling, Communication, and Analysis. Springer, Berlin (2005)

4. Goikoetxea, A.: Enterprise Architecture and Digital Administration: Planning Design and Assessment. World Scientific Publishing Co. Pvt. Ltd., Singapore (2007) 
5. Saha, P.: Handbook of Enterprise Systems Architecture in Practice, IGI Global (2007)

6. WolframMathWorld, http://mathworld.wolfram.com/Dimension.html

7. Zachman, J.: A Framework for Information Systems Architecture. IBM Systems Journal 26(3) (1987)

8. Goethals, F.: An Overview of Enterprise Architecture Deliverables, http://www . cioindex.com/nm/articlefiles/64015-

Goethalsoverviewexistingframeworks.pdf

9. Diehl, M.: FEAF level IV matrix,

http: / / www.markdiehl.com/FEAF/feaf_matrix.htm

10. Enterprise Architecture Space Organizing Table, http://download.microsoft. com/download/0/C/4 / 0C44F7EB-893F-4048-B2C6-C1C889E06DF1/ MOAG_F02.pdf

11. Zacarias, M., Caetano, A., Magalhaes, R., Pinto, H.S., Tribolet, J.: Adding a human perspective to enterprise architectures. In: 18th International workshop on database and Expert systems applications, Italy, pp. 840-844 (2007)

12. Robinson, P., Gout, F.I.: Extreme Architecture Framework: A minimalist framework for modern times. In: Saha, P. (ed.) Handbook of Enterprise Systems Architecture in Practice, IGI Global, pp. 18-36 (2007)

13. Spadoni, M., Abdomoleh, A.: Information Systems Architecture for business process modeling. In: Saha, P. (ed.) Handbook of Enterprise Systems Architecture in Practice, IGI Global, pp. 366-380 (2007) 